\title{
Sustainable Rammed Earth Structure: A Structurally Integral, Cost-Effective And Eco- Friendly Alternative to Conventional Construction Material
}

\author{
Pavan Totla, Maurya Sadwilkar, Samidha More, Blessy Kallada, Bhalchandra Deshmukh, \\ Akshata Puranik
}

\begin{abstract}
While constructing (developing) any structure (asset), its impact on the environment should always be assessed. As we know, cement is a key building material that is commonly used but also creates pollution during its manufacturing, storage handling, transportation and usage. So, what-if this building material can be significantly replaced by some other building material that is far eco-friendlier. Mother Nature i.e. our planet Earth offers us naturally existing and abundant Soil (mud) that can be used as an alternative building material. Cement, as a main component of construction material mix, when replaced by naturally and locally available mineral soil (in different proportions) will result in reduced carbon footprints which otherwise is high for cement supply chain.
\end{abstract}

This nature's gift in the form of mineral soil has inspired the idea of Rammed Earth Construction. This is not an invention; it is an innovation through traditional (well placed) wisdom. Natural soil with additives (if required) in designed/customized amount are compacted in layers within sturdy formwork. From series of field experiments we conducted, the proportions for the components like Soil, (part) Cement and Fly Ash were determined. The proportion of these constituents mainly depends on local availability and climatic condition in \& around the construction site. The resultant construction product mix is a monolithic wall structure with superior thermal insulation properties, fire resistant and most importantly eco-friendly. . The Due to use of soil, the wall absorbs heat during day time and slowly cools down in night time. This phenomenon results in effective insulation system. This moderates daily temperaturevariations and reduces the need for HVAC systems, which helps in attaining the green building objective.

One of the prominent features of Rammed Earth Structure is its cost efficiency. The main component is naturally available

Revised Manuscript Received on September 10, 2019.

Prof. Pavan Totla, Assistant Professor (Grade I), National Institute of Construction Management and Research, Pune, Maharashtra, India

(email id: pavan_totla@yahoo.com)

Maurya Sadwilkar, Project Engineering and Management, National Institute of Construction Management and Research, Pune, Maharashtra , India

(Email id: mauryasadwilkar@gmail.com)

Samidha More, Project Engineering and Management, National Institute of Construction Management and Research, Pune, Maharashtra, India

(Email id: moresamidha1995@gmail.com)

Blessy Kallada, Project Engineering and Management, National Institute of Construction Management and Research, Pune, Maharashtra, India.

(Email id: blessyjk4@gmail.com)

Bhalchandra Deshmukh, Project Engineering and Management, National Institute of Construction Management and Research, Pune, Maharashtra, India

(Email id: apdabhilash7@gmail.com)

Akshata Puranik, Project Engineering and Management, National Institute of Construction Management and Research, Pune, Maharashtra, India

(Email id: akshatapuranik28@gmail.com) mineral soil and other resources required are also available at a comparatively low cost. A structure (say home wall) can be built using Rammed Earth in approximately 1/5thcost than that required for Stone wall. So, Rammed Earth based construction projects can be linked to Government's Low-Cost Housing schemes like Pradhan Mantri Awas Yojana (PMAY, PMGAY). For building Rammed Earth Structures, unskilled labors can be easily trained and hence creates a good opportunity to employ unemployed people including locals. In this way this project can tangibly contribute to bring about a socioeconomic shift/change.

Keywords: Cost Efficiency, Mineral Soil, Socioeconomic, Sustainable Home.

\section{INTRODUCTION}

Rammed earth has a long and continued history throughout many regions of world. In today's pursuit of sustainable development, earthen structures hold a great significance. Rammed earth walls are formed by compacting damp soil between temporary forms. Major cities of rammed earth construction include North Africa, Australia, Regions of North and South America, China and Europe including France, Germany and Spain. The Great Wall of China has some sections built of rammed earth, still intact after 2000 years. Earthen structures are time tested, affordable, easily procurable and more responsive to the local environmental conditions.

This technique has been used worldwide for hundreds of years, whether it is a monumental structure or a simple house. But it can be found from history that the Rammed earth technique has been used in regions having arid climate, like Australia, China etc. Today, various experiments are being performed to improve the properties of Rammed earth and make its use more global.

The key feature in monolithic construction of rammed earth wall, as it removes the use of joints and mortar, increasing the earthquake resistance of the structure. The process involves selection of proper soil sample. It is then sieved and mixed with additives and appropriate amount of water (OMC: optimum moisture content). Suitable mixture is obtained by trial and error. Main weakness of earth is its low resistance to water, thus different additives are used to stabilize the earth and enhance its geotechnical properties.

The aim is to assess the relevance of rammed earth construction in India and contribute in its field. The

\section{Published By:}




\section{Sustainable Rammed Earth Structure: A Structurally Integral, Cost-Effective and Eco-Friendly Alternative to Conventional Construction Material.}

objective is to develop the relevance of rammed earth construction in a certain region in order to bring it into mainstream line of construction.

\section{A. Advantages}

- Ramming requires little water, which can be an important consideration in dry climates with scarcity of fresh water.

- $\quad$ They require few other resources like additives to improve their properties.

- $\quad$ Earth can be recycled, is easy and agreeable to work.

- It has good insulating properties if built with high thermal mass especially for hot climate.

- Known fact, earth gives off no harmful emissions.

- Good for noise reduction and insulation.

- $\quad$ Earth doesn't burn, so rammed earth walls are fire proof.

- $\quad$ Load bearing, which reduces the need for structural supports, therefore reducing building costs. Standard $400 \mathrm{~mm}$ thick rammed earth walls can be used as load bearing in construction up to 4 stories high.

- Termites and other pests are of little concern to rammed earth walls.

\section{B. Disadvantages}

- It is labour-intensive to build.

- $\quad$ Some degree of carpentry skills is needed to build the formwork.

- The ramming itself is relatively time-consuming.

\section{METHODOLOGY}

1) The Steps Involved in preparation of Earth (Mud) which is to be used.

- Excavation

- $\quad$ Screening

- Pulverization

- $\quad$ Mixing

- Casting

- Testing

2) Tests performed:

- $\quad$ Spray Test

- $\quad$ Drip Test

- Drop Test

- Compressive Strength Test

3) Designing a prototype of rammed earth structure.

4) Preparing a cost analysis for a Prototype of Earthen Home.

5) Field Visit

\section{FIELD VISIT}

As our study is related to rammed earth structure, to get more detailed information we visited Mr. Vamshi Das's place situated in Ravet, Pune, Maharashtra, since his house is constructed of rammed earth structure. We could get some idea about the requirements of material as well as the challenges faced while constructing. The advantages and the room for improvement were as follows:

\section{A. Advantages}

- As compared to the outside temperature the temperature inside the house is approximately 2-3 degree less without any use of HVAC.

- The house is ecologically sustainable and ecofriendly.

- Locally available material can be used for the construction.

- The rammed earth structures are bio degradable whereas concrete is not.

- In a way, rammed earth structures are also useful for human health. (E.g. In modern houses, the flooring are very smooth and it leads to joint pain in people above mid age but the mud flooring results in acupressure effect and reduces the joint pain.

\section{B. Room for improvement}

- $\quad$ PCC work in toilet and bathroom is required.

- Leakage is observed on the toilet and bathroom walls.

\section{Limitations}

- $\quad$ Shape constraint.

- No black cotton soil should be used and the best suited is the laterite soil and red mud.

- Convincing people.

\section{Photos Related to Field Visit}

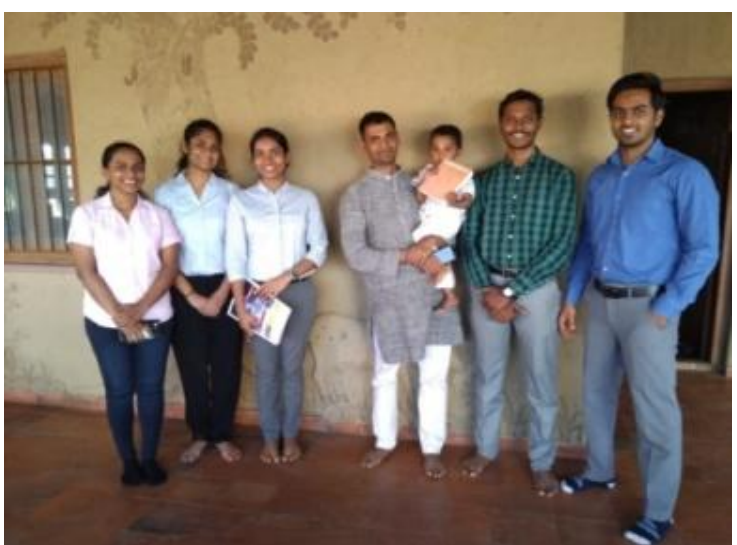

Fig. 1.Field Visit to Mr. Das's House

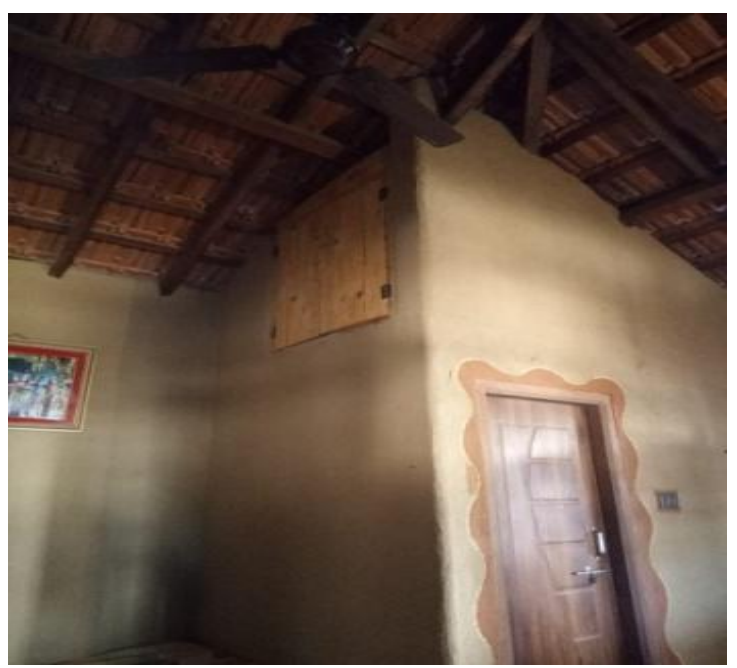

Fig. 2.Wooden Roofing 


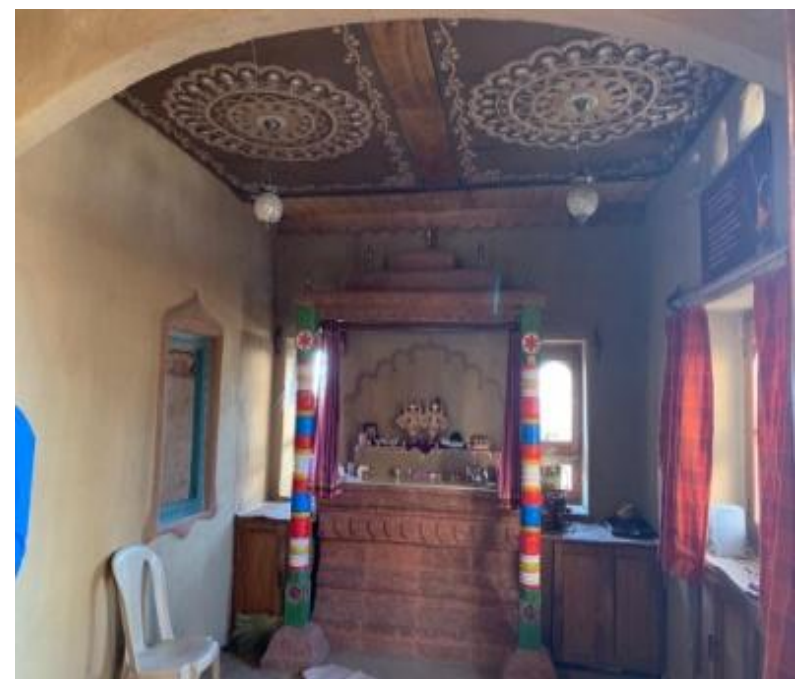

Fig. 3.Laterite Stone Work

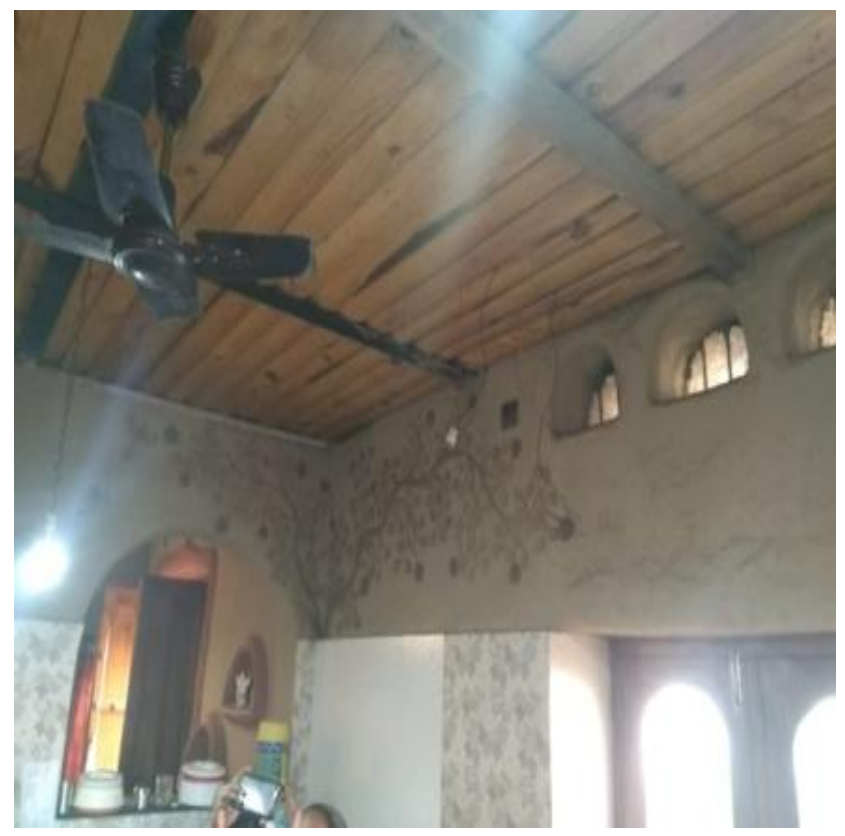

Fig. 4.Wall decoration with mud

\section{TEST RESULTS AND COST ANALYSIS}

\section{A. Compression Test}

Casting of test blocks was carried out using the below mentioned four compositions. 4 blocks of each composition were casted and tested on compression testing machine for 7 th day and 28th day result.

Table I. Specimen Compositions

\begin{tabular}{|c|c|c|c|c|c|c|c|}
\hline \multicolumn{2}{|c|}{ Specimen 1 } & \multicolumn{2}{|c|}{ Specimen 2 } & \multicolumn{2}{c|}{ Specimen 3 } & \multicolumn{2}{c|}{ Specimen 4 } \\
\hline $\begin{array}{c}\text { Soil } \\
100 \%\end{array}$ & Soil & $95 \%$ & Soil & $95 \%$ & Soil & $\begin{array}{c}90 \\
\%\end{array}$ \\
\hline $\begin{array}{c}\text { Ceme } \\
\text { nt }\end{array}$ & $0 \%$ & Cement & $5 \%$ & Cement & $0 \%$ & Cement & $5 \%$ \\
\hline $\begin{array}{c}\text { Fly } \\
\text { Ash }\end{array}$ & $0 \%$ & Fly Ash & $0 \%$ & Fly Ash & $5 \%$ & Fly Ash & $5 \%$ \\
\hline
\end{tabular}

Table II. 7th day compression test result

\begin{tabular}{|c|c|c|c|c|c|c|}
\hline $\begin{array}{l}\text { Speci- } \\
\text { men }\end{array}$ & $\begin{array}{c}\text { Weight } \\
(\mathrm{kg})\end{array}$ & $\begin{array}{l}\text { Density } \\
\left(\mathrm{kg} / \mathrm{m}^{3}\right)\end{array}$ & $\begin{array}{l}\text { Average } \\
\text { Density } \\
\left(\mathrm{kg} / \mathrm{m}^{3}\right)\end{array}$ & $\begin{array}{l}\text { Load } \\
\text { (KN) }\end{array}$ & $\begin{array}{l}\text { Strength } \\
\left(\mathrm{N} / \mathrm{mm}^{2}\right)\end{array}$ & $\begin{array}{l}\text { Average } \\
\text { Strength } \\
\left(\mathrm{N} / \mathrm{mm}^{2}\right)\end{array}$ \\
\hline 1. A & 6.3 & 1867.2 & \multirow[t]{2}{*}{1875.5} & 50 & 2.22 & \multirow[t]{2}{*}{2.45} \\
\hline 1. $B$ & 6.36 & 1883.7 & & 60 & 2.67 & \\
\hline $2 . \mathrm{A}$ & 6.49 & 1923.5 & \multirow[t]{2}{*}{1917.9} & 80 & 3.56 & \multirow[t]{2}{*}{4} \\
\hline $2 . B$ & 6.45 & 1912.3 & & 100 & 4.44 & \\
\hline $3 . \mathrm{A}$ & 6.15 & 1823.1 & \multirow[t]{2}{*}{1850.7} & 60 & 2.67 & \multirow[t]{2}{*}{2.89} \\
\hline $3 . B$ & 6.34 & 1878.2 & & 70 & 3.11 & \\
\hline 4.A & 6.79 & 2013.3 & 1984.5 & 120 & 5.33 & 5.11 \\
\hline $4 . B$ & 6.6 & 1955.6 & & 110 & 4.89 & \\
\hline
\end{tabular}

The compressive strength test results after 7 days of curing show that unsterilized soil gives less strength as compare to the other 3 specimens with stabilized soil. At the same time, the strength values obtained from specimen 1 and 3 are nearby, that is unsterilized soil and soil with $5 \%$ fly ash show somewhat similar strength values. Similarly, the trend can be seen in specimen 2 and 4 which contain cement only and cement plus fly ash respectively. But direct conclusion cannot be drawn from these results as these are only after 7 days of curing. After obtaining 28 days results, proper comparison can be done.

Table III. 28th day compression test result

\begin{tabular}{|c|c|c|c|c|c|c|}
\hline $\begin{array}{l}\text { Speci- } \\
\text { men }\end{array}$ & $\begin{array}{l}\text { Weight } \\
(\mathrm{kg})\end{array}$ & $\begin{array}{l}\text { Density } \\
\left(\mathrm{kg} / \mathrm{m}^{3}\right)\end{array}$ & $\begin{array}{l}\text { Average } \\
\text { Density } \\
\left(\mathrm{kg} / \mathrm{m}^{3}\right)\end{array}$ & $\begin{array}{l}\text { Load } \\
\text { (KN) }\end{array}$ & $\begin{array}{l}\text { Strength } \\
\left(\mathrm{N} / \mathrm{mm}^{2}\right)\end{array}$ & $\begin{array}{l}\text { Average } \\
\text { Strength } \\
\left(\mathrm{N} / \mathrm{mm}^{2}\right)\end{array}$ \\
\hline 1. A & 6.33 & 1876.9 & \multirow{2}{*}{1868.5} & 60 & 2.67 & \multirow{2}{*}{2.89} \\
\hline 1. B & 6.28 & 1860.1 & & 70 & 3.11 & \\
\hline 2.A & 6.51 & 1929.7 & \multirow{2}{*}{1923.35} & 90 & 4 & \multirow{2}{*}{4.67} \\
\hline $2 . B$ & 6.47 & 1917 & & 120 & 5.33 & \\
\hline $3 . \mathrm{A}$ & 6.21 & 1839.1 & \multirow{2}{*}{1851.75} & 80 & 3.56 & \multirow{2}{*}{3.56} \\
\hline $3 . B$ & 6.29 & 1864.4 & & 80 & 3.56 & \\
\hline 4.A & 6.77 & 2004.8 & \multirow{2}{*}{2001.7} & 160 & 7.11 & \multirow{2}{*}{6.67} \\
\hline $4 . B$ & 6.75 & 1998.6 & & 140 & 6.22 & \\
\hline
\end{tabular}

The test results after 28 days of curing show that there is no significant rise in strength of unsterilized rammed earth. Specimen 2 and 3, i.e. cement only and fly ash only, have a small increment in their values. But specimen 4 with both cement plus fly ash has shown a noticeable rise in strength value. It might be because of the cement and fly ash increasing the bonding properties of the soil, giving it more strength than others. It is observed that specimen 4 has achieved highest strength of all others, both for 7 days and 28 days of curing, indicating that when cement and fly ash are both used to stabilize the soil the results are satisfactory. 
Sustainable Rammed Earth Structure: A Structurally Integral, Cost-Effective and Eco-Friendly Alternative to Conventional Construction Material.

\section{B. Primary Cost analysis}

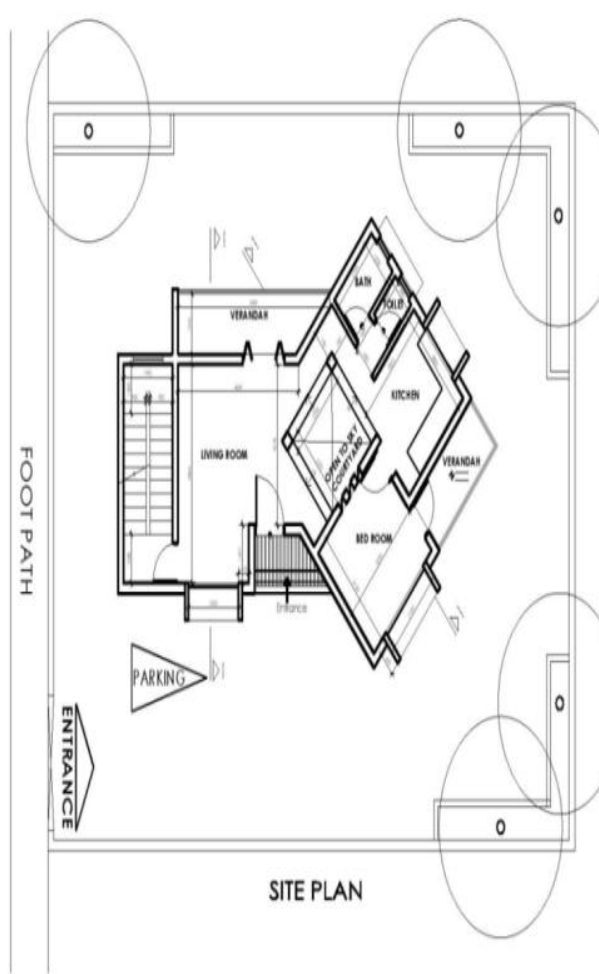

Fig. 5.Design of Proposed Plan

Table IV. Cost Estimation for Rammed Earth Construction

\begin{tabular}{|c|c|c|c|c|}
\hline Item & Unit & Quantity & Rate & Amount \\
\hline Soil & Cu.m & 9 & $400 /-$ & $3,600 /-$ \\
\hline Cement & Bags & 30 & $280 /-$ & $8,400 /-$ \\
\hline \multirow[t]{2}{*}{ Steel } & $\mathrm{Kg}$ & 70 & $50 /-$ & $3,500 /-$ \\
\hline & & & Total & $15,500 /-$ \\
\hline $\begin{array}{l}\text { Head } \\
\text { Mason }\end{array}$ & Days & 5 & $700 /-$ & $3,500 /-$ \\
\hline $\begin{array}{l}\text { Junior } \\
\text { Mason }\end{array}$ & Days & 5 & $500 /-$ & $2,500 /-$ \\
\hline \multirow[t]{2}{*}{ Helper } & Days & 20 & $350 /-$ & $7,000 /-$ \\
\hline & & & Total & $13,000 /-$ \\
\hline \multicolumn{4}{|c|}{ Tools and Plants $30 \%$} & $8,550 /-$ \\
\hline \multicolumn{4}{|c|}{ Add $2 \%$ contingencies } & $570 /-$ \\
\hline \multicolumn{4}{|c|}{ Total } & $37,620 /-$ \\
\hline
\end{tabular}

For 1 cu.m $=37,620 / 10=3,762 /-$

So, total for 1 cum is round about $3,800 /-$
Table V. Cost Analysis of Mangalore Tiles Roof (600 Sq.ft)

\begin{tabular}{|c|c|c|c|c|}
\hline Item & Unit & Quantity & Rate & Amount \\
\hline $\begin{array}{c}\text { Principle } \\
\text { rafter } \\
\text { (length X 5" } \\
\text { X 4") }\end{array}$ & Cu.ft. & 43.55 & Rs. 1700/- & $74,035 /-$ \\
\hline $\begin{array}{c}\text { Rafter } \\
\text { (length X } 4 " \\
\text { X 4") }\end{array}$ & Cu.ft. & 34.08 & Rs. 1700/- & $57,936 /-$ \\
\hline \multirow[t]{3}{*}{$\begin{array}{c}\text { Ribs } \\
\text { (length X 9" } \\
\text { X1.5") }\end{array}$} & Cu.ft. & 27.64 & Rs. 1700/- & $46,988 /-$ \\
\hline & & & Total & $1,73,959 /-$ \\
\hline & & & & $\begin{array}{c}\approx \\
1,80,000 /-\end{array}$ \\
\hline \multirow[t]{2}{*}{$\begin{array}{c}\text { Mangalore } \\
\text { Tiles }\end{array}$} & No. & 600 & Rs. 15/- & $9,000 /-$ \\
\hline & & & Total & $1,89,000 /-$ \\
\hline \multicolumn{4}{|c|}{ Add $10 \%$ labour charges } & $18,900 /-$ \\
\hline & & & & $2,07,900 /-$ \\
\hline \multicolumn{4}{|c|}{ Round Off } & $\begin{array}{c}\approx \\
2,10,000 /-\end{array}$ \\
\hline
\end{tabular}

Table VI. Prototype Cost Estimation

\begin{tabular}{|c|c|c|c|c|}
\hline Item & Unit & Quantity & Rate & Amount \\
\hline Plinth & Cu.m & 15 & $\begin{array}{c}\text { Rs. } \\
5000 /-\end{array}$ & $75,000 /-$ \\
\hline $\begin{array}{l}\text { Rammed Earth } \\
\text { Construction }\end{array}$ & Cu.m. & 40 & $\begin{array}{c}\text { Rs. } \\
3800 / \text { - }\end{array}$ & $1,52,000 /-$ \\
\hline \multirow[t]{2}{*}{$\begin{array}{l}\text { Mangalore Tile } \\
\text { Roofing }\end{array}$} & Sq. ft. & 450 & Rs. $350 \%$ & $1,57,500 /-$ \\
\hline & & & Total & $3,84,500 /-$ \\
\hline \multicolumn{4}{|c|}{ Add $2 \%$ Contingencies $+2 \%$ Work Establishment } & $15,380 /-$ \\
\hline & & & Total & $3,99,880 /-$ \\
\hline & & & & $\begin{array}{c}\approx \\
4,00,000 /-\end{array}$ \\
\hline
\end{tabular}

Total cost for building a 450 Sq.ft prototype with Mangalore tile roofing is $4,00,000 /-$ 
Table VII. Cost Analysis of RCC Structure

\begin{tabular}{|c|c|c|c|c|c|}
\hline $\begin{array}{l}\text { Sr. } \\
\text { No. }\end{array}$ & Item & Unit & Quantity & Rate & Amount \\
\hline 1 & Excavation(21.01) & Cu.m & 78 & $139 /-$ & $10,842 /-$ \\
\hline 2 & PCC M15 (24.05) & Cu.m & 7.9 & $5020 /-$ & $39,658 /-$ \\
\hline 3 & $\begin{array}{c}\mathrm{RCC} \text { in Footing } \\
(25.03)\end{array}$ & Cu.m & 9.9 & $5143 /-$ & $50,916 /-$ \\
\hline 4 & $\begin{array}{c}\mathrm{RCC} \text { in Columns } \\
(25.03)\end{array}$ & Cu.m & 10.4 & $5143 /-$ & $53,488 /-$ \\
\hline 5 & $\begin{array}{c}\mathrm{RCC} \text { in Slab } \\
(25.03)\end{array}$ & Cu.m & 9.8 & $5143 /-$ & $50,402 /-$ \\
\hline 6 & $\begin{array}{c}\text { Brickwork } \\
(27.09)\end{array}$ & Cu.m & 35 & $5500 /-$ & $1,92,500 /-$ \\
\hline 7 & $\begin{array}{c}\text { Painting } \\
(36.01+36.14)\end{array}$ & Sq.mt & 120 & $99 /-$ & $11,880 /-$ \\
\hline 8 & Flooring (33.24) & Sq.mt & 50 & $870 /-$ & $43,500 /-$ \\
\hline 9 & Plastering (32.01) & Sq.mt & 120 & $74 /-$ & $8,880 /-$ \\
\hline 10 & $\begin{array}{l}\text { Windows and } \\
\text { Other Opening }\end{array}$ & L.S & - & - & $50,000 /-$ \\
\hline \multirow[t]{2}{*}{11} & Roofing & Sq.mt & 540 & $250 /-$ & $1,35,000 /-$ \\
\hline & & & Total & & $5,97,066 /-$ \\
\hline
\end{tabular}

All rates are subjected to DSR

Adding $2 \%$ contingencies $+2 \%$ work establishment $=$ $23,883 /-$

Therefore Total Cost $=6,20,950 /-$

\section{CONCLUSION}

\section{A. Comparison based on strength}

If the strength results are compared to that of standard brick, then stabilized rammed earth excels in it. Normal compressive strength of a brick is $3.5 \mathrm{~N} / \mathrm{mm} 2$, and the strength of rammed earth stabilized with cement and fly ash, after 28 days curing comes to be $6.67 \mathrm{~N} / \mathrm{mm} 2$, which is greater than the brick. And even if fly ash is used as stabilizer for soil, then also the strength results are good and considerable for rammed earth.

\section{B. Comparison based on Cost}

As per the above cost analysis based on the rammed earth structure and RCC structure it can be clearly seen that the house constructed using rammed earth technique is more cost effective. Also the rammed earth structures are more feasible, environment friendly and sustainable as compared to RCC structures. This also shows that the rammed earth structure is a better alternative to mass and affordable housing systems under various Government schemes, for example Pradhan Mantri Awas Yojana (PMAY) Bank For Agriculture and Rural Development. (NABARD).

\section{SCOPE OF FURTHER WORK}

- Use of naturally available materials in the rammed earth can be studied for increasing durability and strength.
- Modern techniques can be included in the process of construction of rammed earth for ease and reducing intense labour work.

- Hybrid structure might have potential for building big structures.

- Use of tensile reinforcement in the formwork is another area of research

- The technique has its major use in low cost housing projects, and proper funding technical support can open a very interesting dimension to green building materials.

- $\quad$ Structural analysis of existing structure.

- Checking the feasibility of this project with the help of knowledge areas of Project Management.

- $\quad$ Preparing a business plan for commercialization of rammed earth structure.

- $\quad$ Analyzing the Business Plan.

- $\quad$ Preparation of project proposal for approaching various State/National agencies.

\section{REFERENCES}

1. Wen Pan. Prefabrication and Automation in Rammed Earth Building Construction. 2012. Retrieved from Advanced Construction and Building Technology for Society Publication 376.

2. Ignacio-Javier Gil-Crespo.Late Medieval Castles Built with Rammed Earth in Castle, Spain. 2017. Retrieved from Journal of Architectural Engineering, Volume 23.

3. David Easton. The Rammed Earth House. 1996. Retrieved from The Rammed Earth House eBook ISBN978-1-603581-59-2.

4. Peter Walker. Rammed Earth: Design and Construction Guidelines.

5. D.Ciancio \& C. Beckett. Rammed Earth Construction: Cutting Edge Research on Traditional and Modern Rammed Earth.

6. DaniealCiancio. Rammed earth: An overview of a sustainable construction material.

7. MarwaDabaieh. Building with Rammed Earth-A Practical experience with Martin Rauch.

8. B. V. Venkatarama Reddy. (2013). Sustainable Building Technologies.

9. Bly Windstorm and Aron Schmidt. A Report of Contemporary Rammed Earth Construction and Research in North America. 2013. Retrieved from Sustainability ISSN 2071-1050.

10. Vasilios Maniatidis and Walker. Structural.2008. Retrieved from Journal of Materials in Civil Engineering. Volume 20

11. Abhirami Suresh and K. B. Anand. Strength and Durability of Rammed Earth for Walling. 2017. Retrieved from Retrieved from Journal of Architectural Engineering, Volume 23.

12. Government of Maharashtra PWD e-DSR for year 2017 18

13. IS: 2110-1980 (Reaffirmed 2002) Indian Standard: Code of Practice of Insitu construction of walls in buildings with Soil Cement.

14. Deb Dulal Tripura, S.M.ASCE; and Singh. Characteristic Properties of Cement Stabilized Rammed Earth Blocks.2015. Retrieved from Journal of Materials in Civil Engineering. Volume 27. 


\section{Sustainable Rammed Earth Structure: A Structurally Integral, Cost-Effective and Eco-Friendly Alternative to Conventional Construction Material.}

\section{AUTHORS PROFILE}

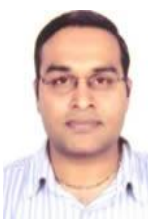

Prof. Pavan Totla, author has completed Chemica engineering with 16 years of professional work experience that includes teaching, oil and gas technology/chemical technology/mechanical (static and piping)/process design, modeling and simulation, pipeline engineering in reputed universities in India both at Under Graduation and Post Graduation level(includes Engineering \& MBA, PG courses). The author has done International training in oil and gas according to IADC, IWCF and official Norwegian vg2 standards for Indian and African students. Have also worked in a petrochemical company. Carrying out industry consultancy including designing courses and training modules, academic administration. In 2008 and 2009, the author has undergone trainer's training in Drilling and Well Services Technology at Stavanger, Norway. The author has also undergone training in Scaffolding and safety conducted by Perth Training Center, Australia. Research publications in conference and journals. Have written case studies. Pursuing PhD from UPES Dehradun.

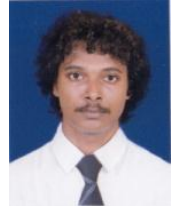

Mr. Maurya Anand Sadwilkar, Author has completed his B.E. Civil from Mumbai University in the year 2017, currently Pursuing Post Graduation in Project Engineering and Management from National Institute Of Construction Management And Research, Pune. Author has done research on rammed earth for last three years in Konkan Region. The base of the research was to test the adaptability of rammed earth in coastal region. The paper is result of partial work done and further experiments are going on. Previous research done by author was only restricted upto certain region, but now the author is in effort to collect data at PAN India Level.

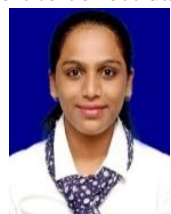

Miss. Samidha Ratnakar More, Author has completed her B.E. Civil from Mumbai University in the year 2017, currently Pursuing Post Graduation in Project Engineering and Management from National Institute of Construction Management And Research, Pune. Author has participated in International Conference on sustainable development in design and manufacturing (ICSDDM-2017), for presenting the work done in her thesis at under graduation level on "Utilization of plastic waste in flexible pavement". The research work carried out by the author on rammed earth is the part of the thesis work in the Post Graduation Programme; it is an extension of the work done by Mr. Maurya Anand Sadwilkar in his B.E project work. The author is now working on further improvements on rammed earth structure.

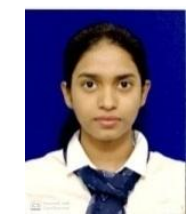

Miss. Blessy Joseph Kallada Author has completed her Bachelor's Degree in Civil from Pune University in the year 2017, currently pursuing Post Graduation in Project Engineering and Management from National Institute of Construction Management And Research, Pune. The author has carried out her Graduation level thesis work on "Identification and Suggestion of Energy Efficient Building Materials" and has presented a paper for the same at the International Conference on Energy and Environment ICEE-2019.The present research is a part of the thesis work at Post Graduation Level.

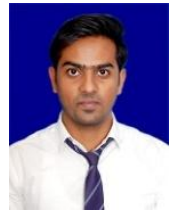

Mr. Bhalchandra Arunrao Deshmukh Author has completed his B.E. Civil from North Maharashtra University in the year 2017, currently Pursuing Post Graduation in Project Engineering And Management from National Institute Of Construction Management And Research, Pune. The author has worked on the concept of "Self Healing Bacterial Concrete" in his under graduation thesis work. The author's current research work is a part of his thesis work in the post graduation programme.

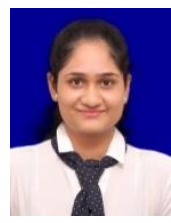

Miss. Akshata Arun Puranik Author has completed her B.E. Civil from Shivaji University in the year 2017 currently Pursuing Post Graduation in Project Engineering And Management from National Institute Of Construction Management And Research, Pune. The author has also done a thesis work on "Ecofriendly road construction and New Trends In Pradhan Mantri Gram Sadak Yojana (PMGSY) Roads" and has presented a paper on the same at "International Conference on Advanced Trends In Engineering" during under graduation level. This research was is a part of thesis work at post graduation level. 